\title{
SEPEDA STATIS SEBAGAI PEMBANGKIT ENERGI LISTRIK ALTERNATIF DENGAN PEMANFAATAN ALTERNATOR BEKAS
}

\author{
Mursyid Al Amin ${ }^{1}$, Rustam Asnawi ${ }^{2}$ \\ ${ }^{1,2}$ Jurusan Pendidikan Teknik Elektro FT UNY \\ Email: mursyid.maa@gmail.com
}

\begin{abstract}
The purpose of this research is to design and make a mechanical device on a static bike used to drive the alternator and find out the performance of the tool. The method used in the research is the design method which includes several stages, namely (1) needs analysis, (2) system design, (3) tool making, and (4) performance testing tool. This tool works using the human power source by pedaling a static bike so that it can rotate the alternator to produce voltage which is then stored in the element of electrical energy storage (battery). The electrical energy stored in the battery can be used to serve simple household electronic appliances that have low power. Based on the results test for 20 minutes, it can be concluded that the tool system of alternative electric power generation can work properly at $2000 \mathrm{rpm}$ to $3600 \mathrm{rpm}$ and produce an average voltage of 14.43 volts and the average charging current of 1.65 amperes.
\end{abstract}

Keywords: Static bike, Alternator, Accumulator, alternative energy

\begin{abstract}
ABSTRAK
Tujuan penelitian ini adalah untuk merancang dan membuat alat mekanik pada sepeda statis yang digunakan untuk menggerakkan alternator serta mengetahui unjuk kerja alat. Metode yang digunakan dalam penelitian adalah metode rancang bangun yang meliputi beberapa tahapan yaitu (1) analisis kebutuhan, (2) perancangan sistem, (3) pembuatan alat, dan (4) pengujian unjuk kerja alat. Alat ini bekerja menggunakan sumber tenaga manusia dengan cara mengayuh sepeda statis sehingga dapat memutar alternator untuk menghasilkan tegangan yang kemudian disimpan dalam elemen penyimpanan energi listrik (baterai). Energi listrik yang tersimpan dalam baterai dapat digunakan untuk melayani peralatan elektronik rumah tangga sederhana yang tidak memiliki daya listrik terlalu besar. Berdasarkan hasil pengujian selama 20 menit yang telah dilaksanakan maka dapat disimpulkan bahwa alat sistem pembangkit energi listrik alternatif ini dapat bekerja dengan baik pada putaran $2000 \mathrm{rpm}$ sampai dengan $3600 \mathrm{rpm}$ dan menghasilkan tegangan rata-rata sebesar 14,43 volt serta arus pengisian rata-rata sebesar 1,65 ampere.
\end{abstract}

Kata Kunci : Sepeda statis, Alternator, Akumulator, energi alternatif

\section{PENDAHULUAN}

Mengingat terbatasnya pasokan energi listrik dari PLN, maka dibutuhkan sumbersumber energi listrik lain yang dapat digunakan masyarakat sebagai solusi dari ketergantungan terhadap kebutuhan energi listrik dari PLN. Adapun salah satu cara mengatasi hal tersebut yaitu dengan memanfaatkan pembangkit energi listrik alternatif. Energi alternatif yang dapat digunakan sebagai pembangkit listrik rumah tangga sederhana adalah pembangkit listrik dari kayuhan pedal sepeda statis yang dikayuh dari tenaga manusia. Pembangkit listrik dari kayuhan pedal sepeda statis merupakan suatu cara sederhana membangkitkan energi listrik untuk konsumsi di dalam rumah tangga sederhana.

Adapun caranya dengan memodifikasi sepeda statis sedemikian rupa sehingga dapat dimanfaatkan untuk menggerakan sebuah alternator sehingga bisa menghasilkan energi listrik, sehingga energi manusia yang digunakan untuk mengayuh sepeda statis ini 
tidak terbuang percuma. Kemudian energi listrik yang dihasilkan dari alternator tersebut disimpan dalam elemen penyimpanan energi listrik (baterai). Energi yang tersimpan dalam baterai dapat digunakan untuk menyalakan peralatan rumah tangga, seperti lampu, televisi, dan beberapa peralatan listrik lainnya yang memiliki daya listrik tidak terlalu besar.

Sepeda yang digunakan oleh masyarakat banyak ragamnya dan jenisnya, salah satunya adalah sepeda statis. Sepeda statis adalah suatu alat olahraga indoor sepeda sederhana yang memiliki roda-roda di depannya sebagai pemberat yang kemudian dikayuh menggunakan pedal, sehingga roda-roda tersebut berputar. Sepeda statis merupakan sarana pengganti dari sepeda biasa bagi orang yang malas berolahraga di luar. Salah satu hal yang terbaik mengenai sepeda statis adalah banyak diminati oleh kalangan masyarakat yang gemar berolahraga. Selain itu, sepeda statis juga sebagai sarana latihan olahraga yang ramah lingkungan dan memberikan banyak manfaat bagi kebugaran tubuh manusia, seperti memertahankan daya tahan tubuh, menyehatkan organ jantung, mengencangkan otot-otot, memperkuat kerangka tubuh, tidak mudah terserang penyakit, menghalau keluhan sakit pinggang pada punggung, pembakar kalori dalam tubuh dan menyeimbangkan sistem metabolisme.

Saat ini, sepeda statis ini terus mengalami perkembangan baik dalam bentuk konstruksi maupun segi fungsi. Tanpa merubah fungsi utamanya sebagai sepeda, namun dengan gerakan latihan berbeda yang lebih banyak, sehingga memudahkan untuk melakukan gerakan yang berbeda dengan menggunakan satu alat olahraga.

Alternator adalah generator untuk menghasilkan arus bolak-balik (generator sinkron). Pada alternator, kumparan yang diam berada di luar dan mengitari medan magnet yang berputar. Jika magnet berputar, maka arah kutub magnet yang diterima oleh kumparan akan berubah-ubah. Hal ini menyebabkan terjadi tegangan induksi pada penghantar yang arahnya juga berubah-ubah. Makin tinggi putaran, maka tegangan induksi pada pengahantar tersebut makin tinggi (Sistem Kelistrikan dan Elektronika pada Kendaraan: 204).

GGL induksi (Ea) pada alternator akan terinduksi pada kumparan jangkar alternator (misalnya kumparan jangkar ditempatkan adalah di stator) bila rotor di putar di sekitar stator (misalnya kumparan medan di rotor). Besarnya kuat medan pada rotor dapat diatur dengan cara mengatur arus medan (If) yang diberikan pada rotor. (Zuriman Anthony, 2010: 21-22)

Arus listrik dibangkitkan dalam kumparan pada saat kumparan diputarkan dalam medan magnet. Jenis arus listrik yang dibangkitkan adalah arus bolak-balik yang arah alirannya secara konstan berubah-ubah dan merubahnya menjadi arus searah, diperlukan sebuah komutator dan brush (sikat-sikat), ini adalah untuk menarik arus searah yang dibangkitkan pada setiap stator coil. Armatur dengan komutator dapat diputarkan di dalam kumparan. Akan tetapi, konstruksi armatur akan menjadi rumit dan tidak dapat diputarkan pada kecepatan tinggi. Kerugian yang lainnya adalah bahwa arus mengalir melalui komutator dan brush (sikat-sikat), maka keausan akan cepat terjadi karena adanya lompatan api.

Untuk mendapatkan arus searah dapat dilakukan dengan cara menyearahkan arus bolak-balik yang dihasilkan oleh stator coil tetap sebelum dijadikan output dengan menggunakan rectifier, atau dengan cara mengganti putaran stator coil dengan memutarkan magnet dalam kumparan. Semakin besar volume listrik yang dibangkitkan di dalam kumparan, maka kumparan semakin panas dikarenakan aliran arus. Oleh karena itu, pendinginan akan menjadi lebih baik kalau stator coil ditempatkan di luar dengan rotor coil berputar di dalamnya (Hery Alamsyah, 2007).

Elektromagnet mempunyai inti besi dengan kumparan dililitkan di sekelilingnya. Pada saat arus mengalir melalui kumparan, inti besi akan menjadi magnet. Besarnya magnet 
yang dibangkitkan tergantung besarnya arus yang mengalir melalui kumparan. Jadi pada saat alternator berputar dengan kecepatan rendah arusnya naik, sebaliknya jika alternator berputar dengan kecepatan tinggi arus menurun. Arus mengalir melalui elektromagnet diberikan oleh batrai (akumulator) dan besarnya diatur oleh voltage regulator, maka alternator akan mengalirkan tegangan yang stabil meskipun putaran mesin berubah-ubah.

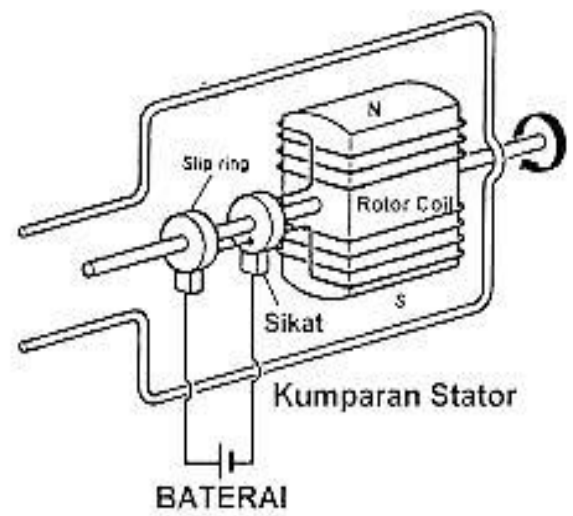

Gambar 1. Kumparan Menghasilkan Elektromagnet

\section{METODE}

Analisis kebutuhan dilaksanakan untuk mengidentifikasi alat dan bahan apa saja yang dibutuhkan untuk pengembangan alat sepeda statis sebagai pembangkit energi listrik alternatif. Pada tahap perancangan dilakukan analisa yang lebih rinci daripada perencanaan. Analisa ini mengenai pemakaian bahan, pemilihan alat bantu, proses pembuatan, serta proses pengujian. Pada tahap ini juga dibuat sebuah blok diagram alat yang nanti akan dibuat. Seperti yang ditunjukkan pada Gambar 2.

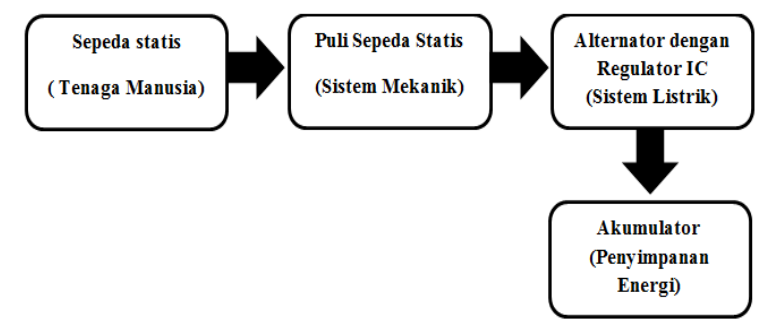

Gambar 2. Diagram Blok Pembangkit Energi Listrik Alternatif dengan Alternator
Puli sepeda statis yang dihubungkan dengan puli alternator melalui sebuah sabuk. Jika sepeda statis dikayuh, maka puli sepeda akan berputar sehingga menyebabkan alternator berputar dengan kecepatan tertentu. Alternator yang berputar akan menghasilkan enegi listrik berupa tegangan dan arus listrik. Tegangan dan arus keluaran dari alternator digunakan untuk pengisian muatan akumulator.

Akumulator yang digunakan memiliki tegangan 12 volt DC. Agar akumulator dapat diisi, maka tegangan keluaran untuk pengisian akumulator harus 13-14 volt DC. Ketika putaran alternator semakin cepat, tegangan dan arus yang dihasilkan akan semakin besar. Oleh karena itu, besarnya tegangan harus distabilkan. Untuk menstabilkan tegangan harus menggunakan regulator. Seperti yang diketahui alternator yang digunakan adalah tipe alternator dengan regulator IC, sehingga tidak perlu menggunakan rangkaian regulator lagi untuk menstabilkan tegangan. keluaran dari alternator ini sendiri sudah menghasilkan tegangan yang stabil 13-14 volt DC.

Lama pengisian akumulator ditentukan oleh besarnya tegangan dan arus yang keluar dari alternator. Semakin besar arus yang dihasilkan oleh alternator, maka semakin cepat pula untuk pengisian akumulator, dengan catatan besar tegangan keluaran alternator yang telah melewati regulator IC adalah 13-14 volt. Jika akumulator sudah terisi penuh, maka dapat langsung digunakan untuk menyuplai peralatan sumber listrik DC (arus searah). Jika peralatan yang digunakan adalah peralatan yang menggunakan sumber listrik AC (arus bolakbalik), maka inverter harus digunakan untuk mengubah tegangan 12 volt DC menjadi tegangan 200 volt AC, sehingga peralatan listrik tersebut dapat digunakan sesuai dengan fungsinya.

Tahap pembuatan alat dimulai dengan mendesaian dudukan alternator dengan software Autocad 2013. Pada awalnya dilakukan pengukuran terlebih dahulu terhadap alternator, ukuran yang diambil berupa panjang alternator, lebar alternator dan tinggi alternator 
sehingga dalam pendesaian dudukan alternator sesuai yang direncanakan. Pembuatan dudukan alternator menggunakan bahan plat besi dengan ketebalan $2 \mathrm{~mm}$. Dudukan Alternator yang akan dibuat terlihat pada Gambar 3.

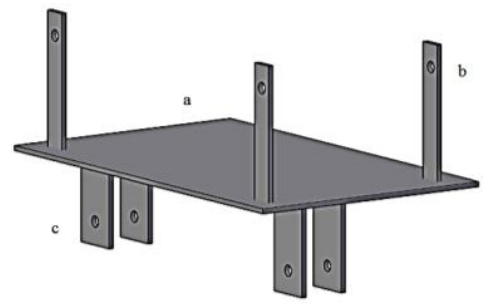

Keterangan :
a. Dasar
b. Tiang penyangga alternator
c. Tiang penyangga sepeda statis

Gambar 3. Dudukan Alternator

Pembuatan hubung puli yang akan dibuat terlihat pada Gambar 4. Puli sepeda statis yang memiliki jari-jari $8 \mathrm{~cm}$ akan dihubungkan ke sebuah alternator yang memiliki jari-jari $3 \mathrm{~cm}$ melalui sebuah sabuk. Fungsi sabuk digunakan sebagai media penggerak, sekaligus sebagai penghubung antara kedua puli tersebut.

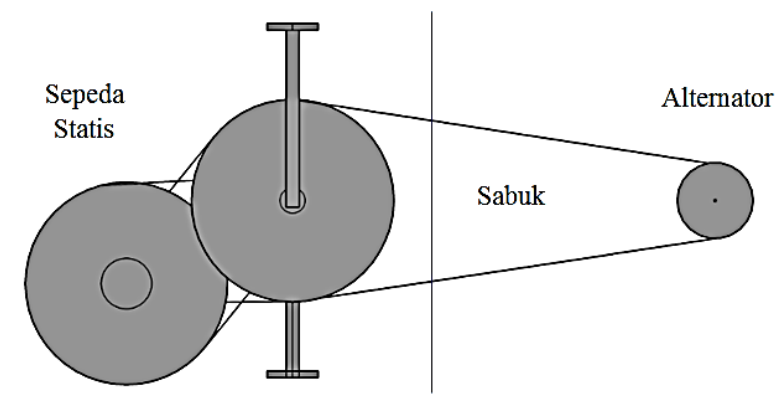

Gambar 4. Hubung Puli Tampak Dari Samping kiri

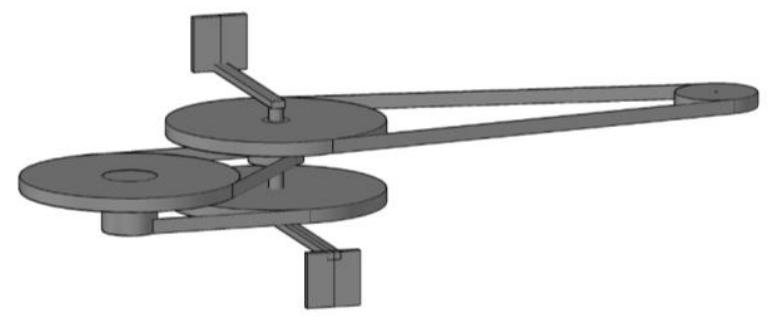

Gambar 5. Hubung Puli Tampak Dari Bawah

Tahap pembuatan penyangga sabuk dilakukan dengan mendesain penyangga sabuk menggunakan software Autocad 2013. Pada awalnya melakukan pengukuran terlebih dahulu dan pengukuran dilakukan dengan menentukan panjang dan lebar, sehingga pembuatan penyangga sabuk bisa dibuat sesuai yang direncanakan. Pembuatan penyangga sabuk ini menggunakan plat alumunium yang memiliki ketebalan $2 \mathrm{~mm}$. Penyangga sabuk digunakan sebagai pengaman atau penahan apabila terjadi penggeseran sabuk terhadap puli. Penyangga sabuk yang akan dibuat terlihat pada Gambar 6 .

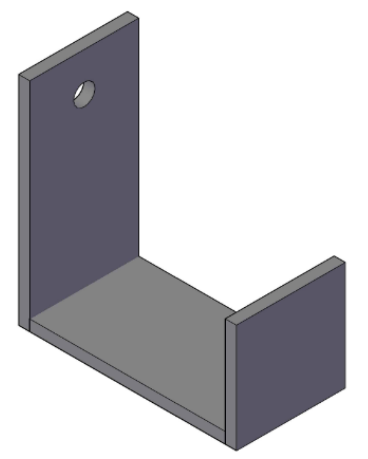

Gambar 6. Penyangga Sabuk

Pengujian pembangkit energi listrik alternatif dengan alternator ini dilakukan dengan dua tahap yaitu : 1) Pengujian terhadap kemampuan alternator untuk menghasilkan tegangan dan arus pada putaran tertentu dan 2) Pengujian pengisian akumulator

Pada pengujian terhadap kemampuan alternator dilakukan untuk mengetahui karakteristik alternator yang akan digunakan. Karakteristik alternator yang ingin diketahui pada saat pengujian adalah tegangan dan arus, serta potensi daya listrik yang dihasilkan oleh alternator pada saat putaran terntentu. Pada pengujian ini akan diketahui pada putaran berapa untuk menghasilkan tegangan dan arus yang nantinya untuk pengisian akumulator.

Pada pengujian pengisian akumulator dilakukan untuk mengetahui kemampuan alternator untuk pengisian akumulator. Pada pengujian ini akan diperoleh tegangan, arus listrik dan kalori yang digunakan untuk mengayuh sepeda statis serta waktu lamanya dalam pengisian akumulator sampai penuh.

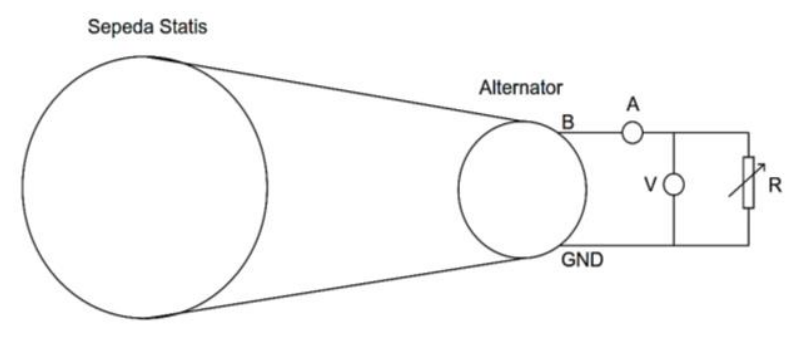


Gambar 7. Rangkaian Pengujian Karakteristik Alternator

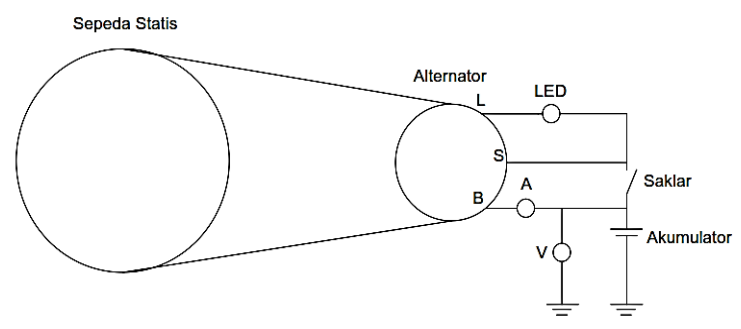

Gambar 8. Rangkaian Pengujian Pengisian Akumulator

Pengujian unjuk kerja sistem pembangkit energi listrik ini dilakukan 2 tahapan, yaitu pengujian terhadap kemampuan alternator untuk menghasilkan tegangan dan arus pada putaran tertentu dan pengujian pengisian akumulator selama 20 menit.

Berikut ini merupakan data yang diperoleh setelah melakukan pengujian unjuk kerja sistem pembangkit energi listrik. Hasil pengukuran tegangan (V), Arus (I), kecepatan rotasi alternator (RPM), kecepatan rotasi pedal sepeda statis (RPM) dan kalori. Pada pengujian ini pengambilan data sebanyak $3 \mathrm{kali}$, sehingga pengukuran data untuk mendapatkan hasil yang lebih akurat.

Tabel 1. Hasil Pengujian Tegangan dan Arus Listrik Output Alternator

\begin{tabular}{|c|c|c|c|c|c|c|c|c|c|c|}
\hline \multirow{2}{*}{ NO } & \multirow{2}{*}{ RPM Pedal } & \multirow{2}{*}{ RPM Alternator } & \multicolumn{4}{|c|}{ TEGANGAN } & \multicolumn{4}{|c|}{ ARUS } \\
\cline { 4 - 11 } & & & $\mathbf{1}$ & $\mathbf{2}$ & $\mathbf{3}$ & Rata-rata & $\mathbf{1}$ & $\mathbf{2}$ & $\mathbf{3}$ & Rata-rata \\
\hline 1 & 9,6 & 400 & 0 & 0 & 0 & 0,00 & 0 & 0 & 0 & 0,00 \\
\hline 2 & 14,4 & 600 & 0 & 0 & 0 & 0,00 & 0 & 0 & 0 & 0,00 \\
\hline 3 & 19,2 & 800 & 0 & 0 & 0 & 0,00 & 0 & 0 & 0 & 0,00 \\
\hline 4 & 24 & 1000 & 0 & 0 & 0 & 0,00 & 0 & 0 & 0 & 0,00 \\
\hline 5 & 28,8 & 1200 & 0 & 0 & 0 & 0,00 & 0 & 0 & 0 & 0,00 \\
\hline 6 & 33,7 & 1400 & 0 & 0 & 0 & 0,00 & 0 & 0 & 0 & 0,00 \\
\hline 7 & 38,5 & 1600 & 0 & 0 & 0 & 0,00 & 0 & 0 & 0 & 0,00 \\
\hline 8 & 43,3 & 1800 & 0 & 0 & 0 & 0,00 & 0 & 0 & 0 & 0,00 \\
\hline 9 & 48,1 & 2000 & 13,76 & 14,03 & 13,93 & 13,91 & 1,56 & 1,53 & 1,54 & 1,54 \\
\hline 10 & 52,9 & 2200 & 14,03 & 14,10 & 13,93 & 14,02 & 1,20 & 1,60 & 1,58 & 1,46 \\
\hline 11 & 57,7 & 2400 & 14,12 & 14,15 & 13,91 & 14,06 & 1,13 & 1,63 & 1,60 & 1,45 \\
\hline 12 & 62,5 & 2600 & 14,17 & 14,09 & 13,89 & 14,05 & 1,14 & 1,62 & 1,63 & 1,46 \\
\hline 13 & 67,3 & 2800 & 14,13 & 14,20 & 13,85 & 14,06 & 1,20 & 1,70 & 1,67 & 1,52 \\
\hline 14 & 72,1 & 3000 & 14,10 & 14,23 & 13,89 & 14,07 & 1,32 & 1,71 & 1,66 & 1,56 \\
\hline 15 & 76,9 & 3200 & 14,03 & 14,17 & 13,88 & 14,03 & 1,41 & 1,73 & 1,67 & 1,60 \\
\hline 16 & 81,7 & 3400 & 13,88 & 14,12 & 13,88 & 13,96 & 1,50 & 1,76 & 1,66 & 1,64 \\
\hline 17 & 86,5 & 3600 & 13,86 & 14,19 & 13,86 & 13,97 & 1,53 & 1,82 & 1,67 & 1,67 \\
\hline
\end{tabular}

Tabel 2. Hasil Pengujian Pengisian Akumulator Selama 20 menit

\begin{tabular}{|c|c|c|c|c|c|c|c|c|c|c|c|c|c|c|}
\hline \multirow{3}{*}{ No } & \multirow{3}{*}{ waktu } & \multirow{3}{*}{ kalori } & \multicolumn{4}{|c|}{ RPM } & \multicolumn{4}{|c|}{ TEGANGAN } & \multicolumn{4}{|c|}{ ARUS } \\
\hline & & & \multicolumn{3}{|c|}{ Percobaan } & \multirow{2}{*}{ Rata-rata } & \multicolumn{3}{|c|}{ Percobaan } & \multirow{2}{*}{ Rata-rata } & \multicolumn{3}{|c|}{ Percobaan } & \multirow{2}{*}{ Rata-rata } \\
\hline & & & 1 & 2 & 3 & & 1 & 2 & 3 & & 1 & 2 & 3 & \\
\hline 1 & 1 & 4 & 3323 & 2970 & 2990 & 3094,3 & 14,25 & 14,30 & 14,27 & 14,3 & 3 & 3 & 3 & 3,0 \\
\hline 2 & 2 & 8 & 2983 & 3534 & 2892 & 3136,3 & 14,26 & 14,21 & 14,29 & 14,3 & 3 & 3 & 3 & 3,0 \\
\hline 3 & 3 & 12 & 3228 & 3356 & 3220 & 3268,0 & 14,26 & 14,25 & 14,23 & 14,2 & 2,4 & 2,6 & 2,8 & 2,6 \\
\hline 4 & 4 & 16 & 3128 & 2821 & 3186 & 3045,0 & 14,13 & 14,05 & 14,16 & 14,1 & 2,2 & 2,3 & 2,5 & 2,3 \\
\hline 5 & 5 & 20 & 2911 & 3145 & 2364 & 2806,7 & 14,34 & 14,10 & 14,31 & 14,3 & 2,2 & 2,1 & 2,4 & 2,2 \\
\hline 6 & 6 & 24 & 3116 & 3130 & 3271 & 3172,3 & 14,34 & 14,33 & 14,37 & 14,3 & 2,1 & 2 & 2,2 & 2,1 \\
\hline 7 & 7 & 28 & 2677 & 2602 & 2684 & 2654,3 & 14,43 & 14,41 & 14,46 & 14,4 & 2 & 2 & 2,1 & 2,0 \\
\hline 8 & 8 & 32 & 2893 & 2841 & 2834 & 2856,0 & 14,39 & 14,36 & 14,21 & 14,3 & 1,8 & 1,8 & 1,8 & 1,8 \\
\hline 9 & 9 & 36 & 2767 & 3280 & 2713 & 2920,0 & 14,47 & 14,49 & 14,26 & 14,4 & 1,8 & 1,7 & 1,7 & 1,7 \\
\hline 10 & 10 & 40 & 3393 & 2740 & 3378 & & 14,45 & 14,31 & 14,4 & 14,4 & 1,7 & 1,7 & 1,6 & 1,7 \\
\hline 11 & 11 & 44 & 3166 & 3104 & 3162 & 3144,0 & 14,49 & 14,44 & 14,48 & 14,5 & 1,6 & 1,6 & 1,5 & 1,6 \\
\hline 12 & 12 & 48 & 2962 & 2907 & 2960 & 2943,0 & 14,53 & 14,49 & 14,51 & 14,5 & 1,6 & 1,6 & 1,5 & 1,6 \\
\hline 13 & 13 & 52 & 3273 & 3176 & 3240 & 3229,7 & 14,35 & 14,27 & 14,39 & 14,3 & 1,5 & 1,5 & 1,4 & 1,5 \\
\hline 14 & 14 & 56 & 2973 & 2503 & 2979 & 2818,3 & 14,42 & 14,48 & 14,48 & 14,5 & 1,4 & 1,5 & 1,2 & 1,4 \\
\hline 15 & 15 & 60 & 2926 & 2710 & 2923 & 2853,0 & 14,51 & 14,50 & 14,5 & 14,5 & 1 & 1,4 & 1 & 1,1 \\
\hline 16 & 16 & 64 & 2729 & 2610 & 2731 & 2690,0 & 14,54 & 14,55 & 14,45 & 14,5 & 1 & 1 & 1 & 1,0 \\
\hline 17 & 17 & 68 & 2736 & 2748 & 2734 & 2739,3 & 14,59 & 14,58 & 14,6 & 14,6 & 0,8 & 0,8 & 0,8 & 0,8 \\
\hline 18 & 18 & 72 & 2697 & 2668 & 2656 & 2673,7 & 14,61 & 14,60 & 14,61 & 14,6 & 0,5 & 0,5 & 0,5 & 0,5 \\
\hline 19 & 19 & 76 & 2672 & 2631 & 2909 & 2737,3 & 14,62 & 14,63 & 14,58 & 14,6 & 0,5 & 0,5 & 0,5 & 0,5 \\
\hline 20 & 20 & 80 & 2721 & 2725 & 3129 & 2858,3 & 14,64 & 14,65 & 14,54 & 14,6 & 0,5 & 0,5 & 0,5 & 0,5 \\
\hline
\end{tabular}




\section{HASIL DAN PEMBAHASAN}

Analisis data hasil pengujian unjuk kerja sistem pembangkit energi listrik ini dilakukan untuk mengetahui kemampuan alternator menghasilkan tegangan dan arus pada putaran tertentu serta lamanya waktu untuk pengisian akumulator. Dari pengujian kemampuan alternator untuk menghasilkan tegangan dan arus pada putaran tertentu, akan diperoleh data berupa tegangan listrik dan arus listrik yang dihasilkan oleh alternator pada saat putaran tertentu. Pada pengujian ini, puli alternator dihubungkan ke puli sepeda statis menggunakan sebuah belt (sabuk). Saat alternator diputar dengan kecepatan putaran tertentu, maka didapat hasil tegangan listrik dan arus listrik yang terukur oleh voltmeter dan amperemeter. Pengujian ini dilakukan dengan menambah kecepatan putaran alternator. Hasil pengujian yang didapat dari pengujian ini ditunjukkan oleh Tabel 1.

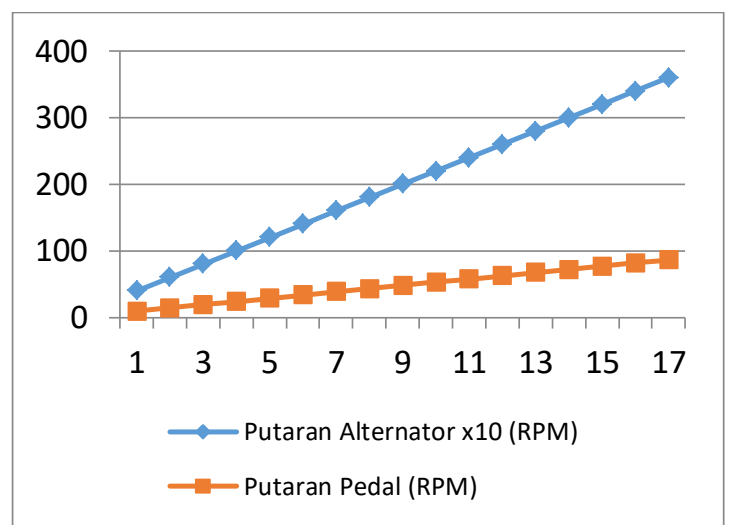

Gambar 9. Grafik Hubungan Antara Kecepatan Putaran Pedal Sepeda Statis dengan Kecepatan Putaran Alternator

Berdasarkan Gambar 9, menunjukkan bahwa kecepatan putar pedal sepeda statis sangat berpengaruh terhadap kecepatan putar alternator. Jika kecepatan putar pedal sepeda statis semakin besar, maka kecepatan putar alternator akan semakin besar dan sebaliknya, jika kecepatan putar pedal sepeda statis semakin kecil, maka kecepatan putar alternator akan kecil. Hal ini menunjukkan bahwa kecepatan putar pedal sepeda statis berbanding lurus dengan kecepatan putar alternator.

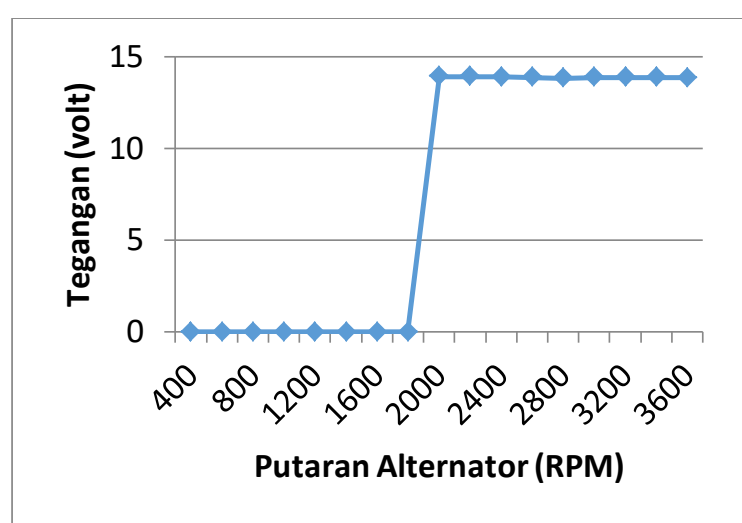

Gambar 10. Grafik Hubungan Antara

Tegangan Output Alternator Terhadap

Kecepatan Putaran Altenator

Berdasarkan Gambar 10, menunjukkan bahwa kecepatan putar alternator sangat berpengaruh terhadap tegangan listrik yang dihasilkan oleh alternator. Jika kecepatan alternator semakin tinggi, maka tegangan listrik yang dihasilkan semakin besar. Hal ini menunjukkan bahwa, kecepatan alternator berbanding lurus dengan tegangan listrik yang dihasilkan oleh alterantor.

Berdasarkan Tabel 1, saat kecepatan putaran alternator $400 \mathrm{rpm}$ sampai dengan 1800 rpm, tegangan output yang dihasilkan oleh alternator sebesar 0 volt, namun pada kecepatan putaran alternator $2000 \mathrm{rpm}$, tegangan yang dihasilkan oleh alternator sebesar 13,93 volt. Hal ini menunjukkan bahwa, kecepatan putaran minimal alternator untuk menghasilkan tegangan untuk pengisian akumulator sebesar $2000 \mathrm{rpm}$. Saat kecepatan putaran alternator mencapai $3600 \mathrm{rpm}$ tegangan yang dihasilkan oleh alternator sebesar 13,97 volt. Hal ini menunjukkan bahwa, batas kecepatan alternator yang cukup untuk pengisian akumulator 12 volt adalah 2000 rpm sampai dengan $3600 \mathrm{rpm}$.

Besar arus listrik yang dihasilkan oleh alternator akan menentukan waktu pengisian akumulator. Semakin besar arus listrik yang hasilkan oleh alternator, maka semakin cepat pula waktu yang dibutuhkan untuk pengisian 
akumulator dan sebaliknya, semakin kecil arus listrik yang dihasilkan oleh alternator, maka semakin lama pula waktu untuk pengisian akumulator.

Tabel 3. Hasil perhitungan daya listrik yang dihasilkan oleh alternator

\begin{tabular}{|c|c|c|c|c|c|}
\hline \multirow{2}{*}{ NO } & \multirow{2}{*}{ RPM Pedal } & \multirow{2}{*}{ RPM Alternator } & \multicolumn{3}{|c|}{ Rata-rata } \\
\cline { 4 - 6 } & & & Tegangan & Arus & Daya \\
\hline 1 & 9,6 & 400 & 0,00 & 0,00 & 0,00 \\
\hline 2 & 14,4 & 600 & 0,00 & 0,00 & 0,00 \\
\hline 3 & 19,2 & 800 & 0,00 & 0,00 & 0,00 \\
\hline 4 & 24 & 1000 & 0,00 & 0,00 & 0,00 \\
\hline 5 & 28,8 & 1200 & 0,00 & 0,00 & 0,00 \\
\hline 6 & 33,7 & 1400 & 0,00 & 0,00 & 0,00 \\
\hline 7 & 38,5 & 1600 & 0,00 & 0,00 & 0,00 \\
\hline 8 & 43,3 & 1800 & 0,00 & 0,00 & 0,00 \\
\hline 9 & 48,1 & 2000 & 13,91 & 1,54 & 21,46 \\
\hline 10 & 52,9 & 2200 & 14,02 & 1,46 & 20,47 \\
\hline 11 & 57,7 & 2400 & 14,06 & 1,45 & 20,43 \\
\hline 12 & 62,5 & 2600 & 14,05 & 1,46 & 20,56 \\
\hline 13 & 67,3 & 2800 & 14,06 & 1,52 & 21,42 \\
\hline 14 & 72,1 & 3000 & 14,07 & 1,56 & 22,00 \\
\hline 15 & 76,9 & 3200 & 14,03 & 1,60 & 22,49 \\
\hline 16 & 81,7 & 3400 & 13,96 & 1,64 & 22,89 \\
\hline 17 & 86,5 & 3600 & 13,97 & 1,67 & 23,38 \\
\hline
\end{tabular}

Kecepatan putar alternator mempengaruhi daya listrik yang dihasilkan oleh alternator. Hal ini menunjukkan bahwa daya listrik yang dihasilkan oleh alternator meningkat seiring dengan meningkatnya kecepatan putar alternator.

Pengujian pengisian akumulator dilakukan untuk mengatahui kemampuan alternator saat pengisian akumulator. Pada pengujian ini, puli pada sepeda statis langsung dihubungkan dengan puli alternator dengan cara dihubungkan sebuah sabuk, kemudian sepeda statis dikayuh dengan putaran tertentu, sehingga bisa memutar puli pada alternator. Kecepatan putar alternator dijaga agar mampu menghasilkan tegangan listrik yang cukup untuk pengisian akumulator. Hal ini dilakukan dengan cara melihat tegangan listrik akumulator yang terukur oleh voltmeter. Besar tegangan listrik minimal yang dibutuhkan untuk pengisian akumulator adalah 12 volt. Pengujian ini dilakukan selama 20 menit.

Data yang diperoleh pada pengujian ini adalah kecepatan putar alternator, kalori yang digunakan, tegangan listrik dan arus listrik yang dihasilkan oleh alternator, serta waktu lamanya untuk pengisian akumulator. Hasil pengujian yang diperoleh dari pengujian ini terlihat pada Tabel 2.

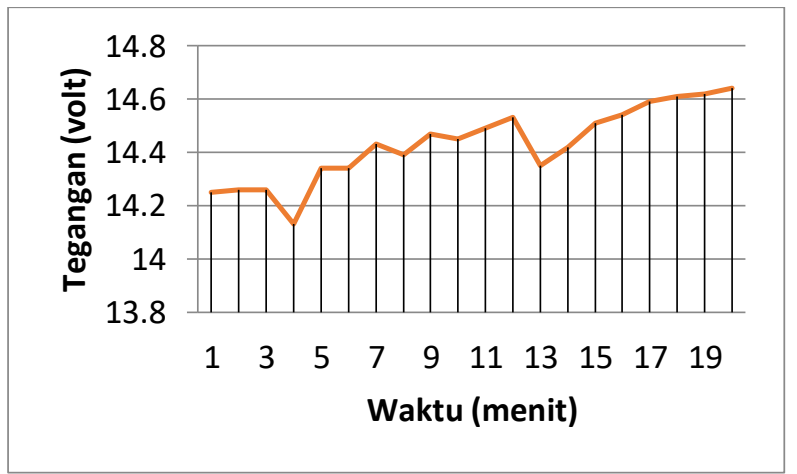

Gambar 11. Grafik Tegangan Listrik Pengisian Akumulator selama 20 menit 
Dari Gambar 11, terlihat bahwa tegangan yang dibutuhkan untuk mengisi akumulator dijaga antara 13 volt sampai dengan 14 volt. Hal ini dilakukan agar aliran arus dari alternator ke akumulator tetap mengalir, karena tegangan listrik alternator lebih tinggi daripada tegangan listrik akumulator.

Tabel 2, juga memperlihatkan arus listrik yang dihasilkan oleh alternator untuk mengisi akumulator. Arus listrik maksimum yang dihasilkan oleh sebesar 3 ampere, sedangkan arus listrik minimum yang dihasilkan oleh alternator sebesar 0,5 ampere dan arus listrik rata-rata yang dihasilkan oleh alternator sebesar 1,65 ampere. Gambar 12 menunjukkan grafik arus listrik yang dihasilkan oleh alternator untuk pengisian akumulator selama 20 menit.

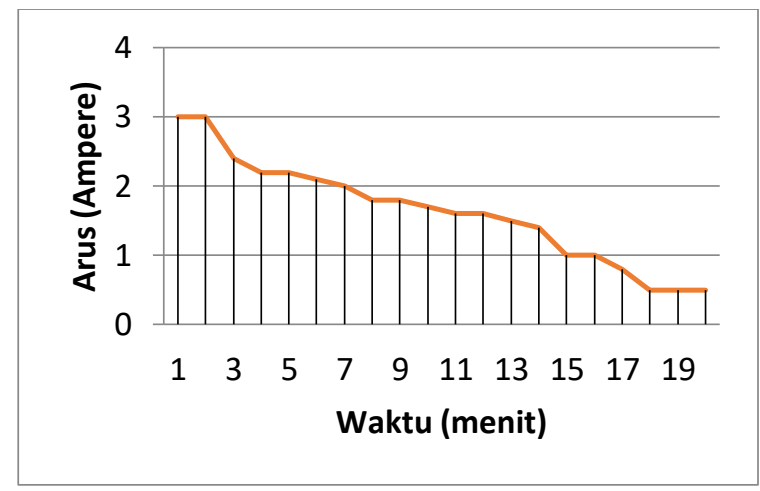

Gambar 12. Grafik Arus Listrik Pengisian Akumulator Selama 20 menit

Gambar 12 juga menunjukkan bahwa, nilai arus listrik pengisian akumulator mengalami penurunan. Penurunan arus listrik tersebut disebabkan karena akumulator sudah terisi penuh. Dari data tersebut dapat disimpulkan, bahwa karakteristik alternator adalah membatasi arus listrik yang masuk ke akumulator saat terisi penuh, sehingga dalam pengisian tidak merusak akumulator dengan kapasitas 3,5 Ah dengan waktu selama 20 menit.

Tabel 2, juga memperlihatkan data kecepatan putar alternator selama 20 menit. Kecepatan putar maksimum yang dihasilkan oleh alternator sebesar $3268 \mathrm{rpm}$, sedangkan kecepatan putar minimum yang dihasilkan oleh alternator sebesar $2654 \mathrm{rpm}$. Dari data Tabel 2, diperoleh nilai rata-rata kecepatan putar alternator sebesar 2940 rpm. Gambar 13 memperlihatkan grafik kecepatan putar alternator selama 20 menit pengujian pengisian akumulator.

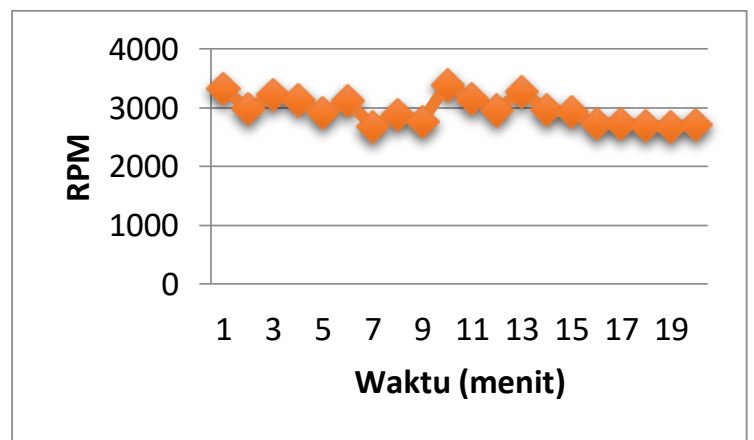

Gambar 13. Grafik kecepatan alternator selama 20 menit

Gambar 13 menunjukkan bahwa nilai, kecepatan alternator cenderung tetap antara $2000 \mathrm{rpm}$ sampai dengan $3600 \mathrm{rpm}$. Hal ini terjadi karena tegangan listrik harus dijaga 13 volt sampai dengan 14 volt, supaya aliran arus listrik dari alternator ke akumulator sehingga pengisian akumulator dapat berlangsung.

Tabel 2, juga memperlihatkan data kalori yang digunakan untuk mengayuh sepeda statis selama 20 menit. Dari data tersebut total kalori yang dibutuhkan untuk mengayuh sepeda statis selama 20 menit sebesar 80 kalori. Hal ini menunjukkan bahwa, semakin lama mengayuh sepeda statis, maka semakin banyak kalori yang digunakan untuk mengayuh sepeda statis.

Pada pengujian ini, tegangan listrik awal akumulator sebelum dilakukan pengisian sebesar 11,60 volt, sedangkan tegangan listrik setelah 20 menit pengisian sebesar 12,84 volt. Hal ini berarti tegangan listrik akumulator bertambah 1,24 volt. Seperti yang diketahui tegangan listrik akumulator saat terisi penuh sebesar 13 volt. Data ini didapat setelah melakukan pengisian akumulator dengan pengisian biasa. Untuk pengosongan akumulator dilakukan dengan mencatu ke beban listrik (lampu). Hasil yang didapat saat pengosongan akumulator dengan mencatu ke beban listrik (lampu) sebesar 10,20 volt. Hal ini menunjukkan bahwa, tegangan listrik 
akumulator yang tidak dapat mencatu ke beban listrik sebesar 10 volt. Dari data kedua tersebut, maka selisih antara tegangan akumulator saat terisi penuh dan tidak dapat mencatu ke beban listrik sebesar 3 volt.

Akumulator yang digunakan pada proses pengisian adalah akumulator yang memiliki kapasitas $80 \%$, maka kapasitas 20\% akumulator yang akan diisi adalah $20 \% \times 3,5 \mathrm{Ah}=0,7 \mathrm{Ah}$. Waktu yang diperlukan untuk mengisi akumulator dari $80 \%$ sampai penuh dimana dengan arus rata-rata pada pengisian akumulator selama 20 menit sebesar 1,63 ampere.

Dari tabel 2, didapatkan hasil tegangan listrik maksimum yang dihasilkan oleh alternator sebesar 14,61 volt, sedangkan tegangan listrik minimum yang dihasilkan oleh alternator sebesar 14,11 volt dan tegangan listrik rata-rata yang dihasilkan oleh alternator sebesar 14,43 volt. Data tersebut menunjukkan bahwa, tegangan listrik yang dihasilkan oleh alternator cukup untuk pengisian akumulator. Gambar 11 menunjukkan tegangan listrik yang dihasilkan selama 20 menit. Berdasarkan perhitungan dari data tersebut yang diperoleh dari hasil pengisian akumulator dengan sistem pembangkit listrik, diperoleh hasil bahwa untuk mengisi akumulator dari keadaan kosong sampai penuh membutuhkan waktu sekitar 0,42 jam atau kisaran 25 menit.

Besar potensi daya listrik yang dapat dihasilkan pada pengujian pengisian akumulator dapat dihitung dengan mengasumsikan nilai faktor daya sama dengan 1, daya listrik maksimum yang dapat dihasilkan sebesar 42,82 watt, sedangkan daya listrik minimum yang dapat dihasilkan sebesar 7,30 watt. Berdasarkan dari data perhitungan tersebut, diperoleh nilai daya listrik rata-rata yang dihasilkan sebesar 23,62 watt.

Dengan mengasumsikan nilai efisiensi sebesar $100 \%$ dan daya listrik yang dihasilkan adalah daya listrik rata-rata 23,62 watt, diperoleh hasil energi listrik yang di hasilkan selama 20 menit pengujian pengisian akumulator sebesar 7,87 watt hour.

\section{SIMPULAN}

Pembuatan sistem pembangkit energi listrik pada sepeda statis dibuat berdasarkan analisis kebutuhan, perancangan, pembuatan, pengujian dan pembahasan. Analisis kebutuhan mulai dari menentukan alat dan bahan. Perancangan mulai dari diagram blok dan rancangan hardware. Pengujian dilakukan sesuai dengan rencana pengujian dari langkahlangkah pengambilan data.

Sistem pembangkit energi listrik alternatif ini dapat menyesuaikan keadaan kayuhan dari tenaga manusia. Sedangkan daya yang dihasilkan belum maksimal. Kecepatan putar alternator minimum yang dibutuhkan untuk memutar alternator sehingga menghasilkan tegangan yang cukup (13 volt sampai dengan 14 volt) untuk pengisian akumulator adalah $2000 \mathrm{rpm}$ atau kisaran mengayuh pedal sepeda statis adalah 48,07 rpm.

Pada pengisian akumulator, sistem pembangkit energi listrik mampu menghasilkan tegangan listrik maksimum 14,64 volt dan tegangan listrik minimum 14,13 volt. Begitu juga pada arus listrik maksimum yang dihasilkan oleh alternator adalah 3 ampere dan arus listrik minimum 0,5 ampere, namun pada pengisian akumulator arus listrik cenderung turun dari 3 ampere hingga 0,5 ampere selama pengujian 20 menit. Hal ini menunjukkan bahwa penurunan arus listrik tersebut menandakan pengisian akumulator sudah penuh. Dari data yang diperoleh untuk waktu pengisian akumulator dari keadaan kosong hingga penuh membutuhkan waktu sekitar 0,42 jam atau 25 menit.

\section{DAFTAR RUJUKAN}

Anonim. t.th-a. Sistem kelistrikan dan elektronika pada kendaraan. Jakarta: Direktorat Pembinaan Sekolah Menengah Kejuruan.

Hery, Alamsyah. 2007. Pemanfaatan Turbin Angin Dua Sudu Sebagai Penggerak 
Mula Alternator pada Pembangkit Listrik Tenaga Angin. Skripsi. Program Sarjana Fakultas Teknik Universitas Negeri Semarang. Semarang. 28-33

Puspitoningrum, Jatmiko. (2006). Komparasi Kekuatan Penyimpanan Energi Listrik pada Akumulator Kering dan Basah pada Tegangan 12 Volt. Tugas Akhir. Program Ahli Madya Fakultas Teknik Unversitas Negeri Semarang, Semarang. 6-25

Setiawan, Agus. (2009). Disain Pembangkit Listrik Tenaga Pedal sebagai Sumber Energi Alternatif di Daerah Pedesaan.
Skripsi. Program Sarjana Fakultas Teknik Universitas Indonesia. Jakarta.

Sunyoto. (1993). Mesin Listrik Arus Searah. Yogyakarta: FPTK IKIP Yogyakarta

Widada, Sri. (2007). Induksi Elektromagnetik. Diambil pada tanggal $06 \mathrm{Mei} 2015$, dari http://smpn5solo.net/wpuploads/fisika/MP_337.html.

Zuriman, Anthony. (2010). Mesin listrik Arus Bolak-balik. Bahan Ajar. Program Studi Teknik Elektro S1 Fakultas Teknologi Industri Institut Teknologi Padang. Padang: 21-22 